\title{
Biology, ecology and bloom dynamics of the toxic marine dinoflagellate Pyrodinium bahamense
}

\author{
Gires Usup ${ }^{\mathrm{a}, *}$, Asmat Ahmad ${ }^{\mathrm{a}}$, Kazumi Matsuoka ${ }^{\mathrm{b}}$, Po Teen Lim ${ }^{\mathrm{c}}$, Chui Pin Leaw ${ }^{\mathrm{d}}$ \\ ${ }^{a}$ Faculty of Science and Technology, Universiti Kebangsaan Malaysia, 43600 Bangi, Selangor, Malaysia \\ ${ }^{\mathrm{b}}$ Institute for East China Sea Research, Nagasaki University, 1-14 Bunkyo-machi, Nagasaki, Japan \\ ${ }^{c}$ Faculty of Resource Science and Technology, Universiti Malaysia Sarawak, 94300 Kota Samarahan, Sarawak, Malaysia \\ ${ }^{\mathrm{d}}$ Institute of Biodiversity and Environmental Conservation, Universiti Malaysia Sarawak, 94300 Kota Samarahan, Sarawak, Malaysia
}

\section{A R T I C L E I N F O}

\section{Article history:}

Available online 25 October 2011

\section{Keywords:}

Harmful algal blooms

Pyrodinium bahamense

HAB biology and ecology

\begin{abstract}
A B S T R A C T
It has been 40 years since the first recorded toxic bloom of Pyrodinium bahamense occurred in Papua New Guinea in 1972. Subsequently this species has increased in importance as a paralytic shellfish poisoning toxin (PSTs) producer in several regions of the world, especially in the Indo-west Pacific. P. bahamense is a thecate tropical/subtropical euryhaline dinoflagellate. Available data indicate that it forms blooms only in waters of $20 \mathrm{psu}$ or higher salinity and at temperatures above $20^{\circ} \mathrm{C}$. It is monospecies with two varieties, namely var. compressum and var. bahamense. For many years it was widely accepted that only var. compressum is toxic and is limited to the tropical Pacific while var. bahamense is nontoxic and is limited to the tropical Atlantic. It is now known, however, that there are at least two locations where the varieties co-occur and it has also been proven that var. bahamense in Florida waters also produce PST. $P$. bahamense has a life cycle typical of many dinoflagellates. It has a heterothallic sexual cycle that produces a large spiny spherical resting cyst. The toxicity profile of $P$. bahamense is also very simple with most isolates producing only dc-STX, STX, neoSTX, B1 and B2 toxins. Further studies are needed in order to resolve the varietal status of the species and also to understand the environmental factors that determine its toxicity and bloom dynamics.
\end{abstract}

(c) 2011 Elsevier B.V. All rights reserved.

\section{Introduction}

The thecate Pyrodinium bahamense is a very important member of paralytic shellfish toxin (PST)-producing marine dinoflagellates especially in tropical waters. This species have caused more human illnesses and fatalities than any other PST producing dinoflagellates. $P$. bahamense gained prominence from the early 1970 s with a spate of toxic blooms in the Indo-Pacific and the Pacific coast of central America. The first confirmed toxic bloom of $P$. bahamense occurred in Papua New Guinea in 1972 (Maclean, 1989). Subsequently first incidences of toxic blooms of the species occurred in Brunei and Sabah, Malaysia in 1976, Manila Bay, the Philippines in 1983, Mindanao, the Philippines in 1983, Ambon, Indonesia in 1994, Palawan Island, the Philippines in 1998 and the Pacific coast of Guatemala in 1987 (Roy, 1977; Maclean, 1989; Rosales-Loessener, 1989; Wiadnyana et al., 1996; Sombrito et al., 2004). At present, $P$. bahamense continues to be a significant cause

\footnotetext{
* Corresponding author. Tel.: +60 3 89213207; fax: +60 389253357.

E-mail addresses: giresusup@gmail.com (G. Usup), asmat@ukm.my (A. Ahmad), kazu-mtk@nagasaki-u.ac.jp (K. Matsuoka), ptlim@frst.unimas.my (P.T. Lim), cpleaw@ibec.unimas.my (C.P. Leaw).
}

of seafood toxicity in Southeast Asia and has also emerged as a potentially important source of toxicity on both the Pacific and Atlantic coasts of central America, including Florida (Landsberg et al., 2006; Martinez-Lopez et al., 2007; Garate-Lizarraga and Gonzalez-Armas, 2011).

Early on $P$. bahamense had a reputation as a very difficult species to culture in the laboratory. It was only since the early 1990s that cultures became routinely available in some laboratories and this opened opportunities for studies on the life cycle, physiology, toxicity and genetics of the species. The first comprehensive review of the species was published in 1998 (Usup and Azanza, 1998) and since then more new knowledge have been generated on this important species. The most profound change in our knowledge of the species arguably has to do with the debunking of the longstanding belief in the non-toxicity of the variety bahamense and the absence of toxic population in the tropical Atlantic.

\section{Taxonomy, history and paleobiology of $P$. bahamense}

\subsection{Taxonomic history}

In 1906, Plate first described $P$. bahamense from the New Providence Island in the Bahamas. Thereafter, Bohm (1931) 